\title{
Environmental and health assessment of soil pollution impact on public health
}

\author{
Valentina Nikiforova*, Svetlana Lapina, and Margarit Vardanian \\ Bratsk State University, Bratsk, Russia
}

\begin{abstract}
The paper considers environmental and health assessment of the soil cover quality in Bratsk, the Irkutsk Region. The purpose of the research: environmental and health assessment of soil pollution impact on the public health when exposed to chemicals formed during aluminium production. The method of analyzing the total fluoride content (in $\mathrm{mg} / \mathrm{kg}$ of soil) on the horizons of $0-5 \mathrm{~cm}$ and $5-10 \mathrm{~cm}$ is used; a volume of the oral, inhaled, and cutaneous intake of this substance from the soil is assessed. Based on the risk assessment of multi-mediated exposure to chemicals, a quantitative characteristic of the total intake of fluoride compounds is given. It's been found that of all the sampling points in Bratsk, the most contaminated with fluoride compounds is the village of Chekanovsky (the maximum content is $1,722 \mathrm{mg} / \mathrm{kg}$ ); the soils of the village of Padun are less polluted (the maximum content is $48 \mathrm{mg} / \mathrm{kg}$ ). The total average daily intake of fluoride compounds for the adult is determined, the values of them don't exceed the human's need for fluoride when calculated per $\mathrm{kg} / \mathrm{body}$ weight. The most sensitive group to environmental pollution, including soil, by fluoride compounds, is children.
\end{abstract}

\section{Introduction}

The soil, along with air and water, is the environment with which a human is directly connected throughout his life. The soil cover is a self-regulating biological system and is one of the components of the Earth's biosphere, determining several processes occurring in it [1]. Soil quality characterizes not only the environmental and health status of land ecosystems but also the quality of the environment as a whole [2].

This problem is especially acute for urbanized territories, the state of which is influenced by some factors [3]. The population in these territories is subject to man-made loads, and therefore the task of reducing the negative impact on the environment is very relevant. To the greatest extent, various aspects of anthropogenic activity are experienced by soils and soil cover [4]. A significant problem for large industrial cities is soil pollution by fluoride, especially in areas with a developed aluminium industry $[2,5]$. Emissions have the greatest adverse effect at a distance of $0.5-1.5 \mathrm{~km}$ from plants, solid particles containing fluoride accumulate at a distance of up to $5 \mathrm{~km}$, and gaseous compounds are detected $30 \mathrm{~km}$ from the emission source [5].

\footnotetext{
* Corresponding author: nikiforovabr@mail.ru
} 
The soil, having high sorption properties, is able to absorb substances from the atmosphere, therefore, the closer to polluting enterprises it is, the sharper increase in the content of fluoride compounds in soils and ground is observed [6, 7, 9]. For example, the greatest soil pollution with fluoride compounds in the city of Shelekhov, the Irkutsk Region, was observed around an aluminium plant within a radius of $1 \mathrm{~km}$, at a distance of up to $8 \mathrm{~km}$, the excess reached 9 MAC for the soil [8]; a significant accumulation of fluorides in the forest litter in the operation area of the Kandalaksha Aluminium Plant (Al-Fe-humus podzols) was revealed: in the zone of maximum pollution ( $2 \mathrm{~km}$ to the plant), the content of fluoride compounds was 5 times higher than the MAC, in the zone of moderate pollution $(5-10 \mathrm{~km})$ -2 times higher [10].

It is known that the criterion for assessing the fluoride pollution of soils and ground is the content excess of total and soluble forms of these compounds over the background. There are several works in which the properties of these compounds are disclosed. According to their chemical properties, alkali metal fluorides are strong water mobile forms capable of migrating to all soil profile horizons [11]. According to A.N. Bobrov, water-soluble fluoride can accumulate in the upper humus soil horizons due to the formation of poorly soluble compounds, for example, in the form of aluminium and calcium salts [12], in addition, the accumulation of fluoride in the soil depends on the type of soil and the depth of the horizon $[5]$.

It should be emphasized that fluoride compounds inhibit photosynthesis, affect the metabolism of plants and can cause a decrease in the rate of oxygen uptake, contribute to their premature ageing, cause respiratory disorders, reduced assimilation of nutrients, a decrease in the content of chlorophyll, suppression of starch synthesis, destruction of DNA and RNA $[13,14]$.

Modern scientific data on the effects of fluoride on the human body attract attention in the aspect of our research problematics $[3,6,8]$.

There are several positions on this issue: with excessive content of fluoride compounds in environmental objects, it causes a toxic effect on various parts of the human body, and, at the same time, being an important trace element, it is necessary for the normal development of the human body.

To date, quite a lot of works have been published showing the features of environmentaldependent diseases of the population under the toxic effects of fluoride compounds [15-17]. So, in his work, I.V. Donskikh [15] observed, regardless of the routes of entry and (or) the conditions of exposure, a toxic effect on a whole complex of organs and systems, including cardio-respiratory, neuroendocrine, musculoskeletal. V.N. Kuvina confirms the correlation with the general incidence and group of musculoskeletal system diseases in children of cities with man-caused pollution [16]. A.Y. Gaskov and co-authors identified elevated levels of fluoride in the bio-substrates of children living in industrial centres; this fact indicates its potential danger to their health and is one of the reasons for the thyroid gland increase in size [17].

Numerous foreign and domestic studies have shown the relationship between public health status and environmental pollution level [8, 16, 18-26].

The increasing influence of anthropogenic impact on the population morbidity makes it necessary to assess the risk of environmental and health factors affecting human health. The methodology of risk assessment of the impact of environmental factors on human health is a promising, intensively developing global scientific direction and an important tool for social and hygienic monitoring.

Carrying out the quantitative assessment of chemicals in the body from the soil factor impact by calculating the dose load on separate population groups seems relevant and effective [6]. 
The purpose of this paper was an environmental and health assessment of soil pollution's impact on public health (using the example of Bratsk, the Irkutsk Region).

\section{Materials and methods}

In selecting the research object, all monitoring points of soil pollution sources in Bratsk, the Irkutsk Region were assessed.

In our research, the environmental and health status of the city's soil cover was estimated based on the analysis of the total fluoride content in soils $(\mathrm{mg} / \mathrm{kg})$ on the horizons of $0-5 \mathrm{~cm}$ and $5-10 \mathrm{~cm}$.

To achieve this goal, a retrospective comprehensive assessment and analysis of laboratory data included in the database of the regional system of social and hygienic monitoring of the Centre for Hygiene and Epidemiology in the Irkutsk Region in Bratsk for the period from 2000 to 2020 was carried out.

Sampling for the detection of fluoride compounds is carried out annually in August at four points located in the Northern $(\mathrm{N})$ and North-Eastern (NE) directions at a distance of 2$30 \mathrm{~km}$ from the functioning aluminium plant of RUSAL Bratsk PJSC:

- village of Chekanovsky $(2 \mathrm{~km}, \mathrm{~N})$;

* Pursey greenhouse farm $(8 \mathrm{~km}, \mathrm{NE})$;

* Telecentre, a district within the city of Bratsk (12 km, NE);

* village of Padun $(30 \mathrm{~km}, \mathrm{NE})$.

Soil pollution was studied by GN 2.1.7.2041-06 "Maximum Allowable Concentration (MAC) of Chemicals in the Soil" [27].

According to the methodology [28] "Temporary methodological guidelines. Determination of fluoride in soil, vegetation, precipitation, in the air and natural waters by the ion-selective electrode method" the conversion of fluoride from micrograms $/ \mathrm{ml}$ to $\mathrm{mg} / \mathrm{kg}$ was performed.

Quantitative assessment of oral, inhaled, and cutaneous intake of a chemical substance into the body from the soil was performed by methodological recommendations for calculating doses when assessing the risk of multi-mediated exposure to chemicals [29].

To confirm the chemical load on the studied subpopulations, analyzing hair for the fluoride content as a specific indicator of atmospheric air pollution was carried out in the laboratory of physicochemical research methods of the AF-Research Institute of MT and EC of the GUNC ME VSNC SB RAMS. The fluoride content was determined in the hair suspension after its mineralization. Fluorides were determined electrochemically using a fluorine-selective electrode of the EKON-R solid-contact type. The potential value of the electrode system against the background of a citrate buffer solution with a $\mathrm{pH}=6.0 \pm 0.5$ was recorded with an ASGO/METK-333 ionomer. The total number of examined people is 62, of which $60 \%$ lived in the Central and $40 \%$ in the Padunsky districts. A cohort of children and adolescents from the city of Severobaikalsk, examined in December 2005 (40 and 25, respectively 4-7 and 18-20 years old), was considered as a control group.

\section{Findings and Discussion}

The city of Bratsk is an industrial centre, where a significant industrial potential is concentrated. Administratively, the city is divided into several districts, which differ in the pollution degree of residential territories.

The largest aluminium plant of RUSAL-Bratsk PJSC operates in the Central District, where the production of the light metal is based on fluoride technology: the molten mixture, which is electrolyzed at $950{ }^{\circ} \mathrm{C}$ to produce aluminium on the cathode, mainly consists of 
cryolite $\mathrm{Na}_{3} \mathrm{AlF}_{6}(87-90 \%)$, and also contains fluorite $\mathrm{CaF}_{2}$, aluminium fluoride $\mathrm{AlF}_{3}$ and aluminium oxide (bauxite). These components of this mixture have very high melting points $\left(\mathrm{T}_{\mathrm{m}}=1000{ }^{\circ} \mathrm{C}\right.$ for $\mathrm{Na}_{3} \mathrm{AlF}_{6}, \mathrm{~T}_{\mathrm{m}}=2050{ }^{\circ} \mathrm{C}$ for $\left.\mathrm{Al}_{2} \mathrm{O}_{3}\right)$, and the mixture of the two main components $\left(82 \% \mathrm{Na}_{3} \mathrm{AlF}_{6}+18 \% \mathrm{Al}_{2} \mathrm{O}_{3}\right)$ melts at only $935{ }^{\circ} \mathrm{C}$. Thus, the use of cryolite and the addition of fluorite and aluminium fluoride, rather than pure aluminium oxide, lowers the melting point of the mixture, but at the same time increases the fluoride content in the exhaust gases. It is established that RUSAL-Bratsk PJSC annually emits more than 4.5 thousand tons of fluoride compounds into the atmosphere.

The analysis of soil samples for the detection of fluoride compounds was carried out by us at the sampling points by the requirements of social and hygienic monitoring.

The levels of the total fluoride content in Bratsk on the horizons of 0-5 and 5-10 cm at the sampling points are shown in Fig. 1 and Fig. 2.

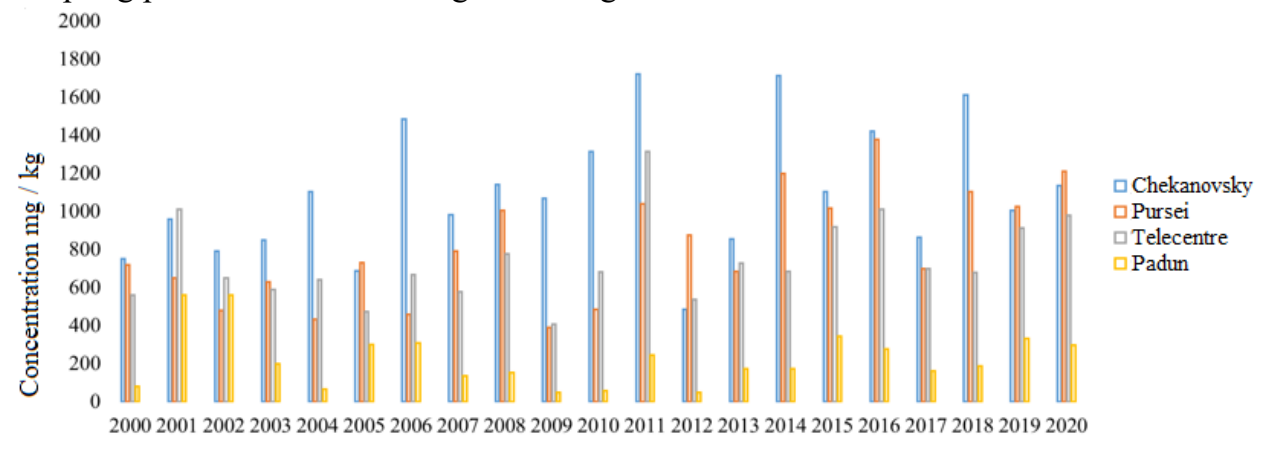

Period, years

Fig. 1. The total fluoride content at the sampling points in Bratsk on the horizon of 0-5 cm.

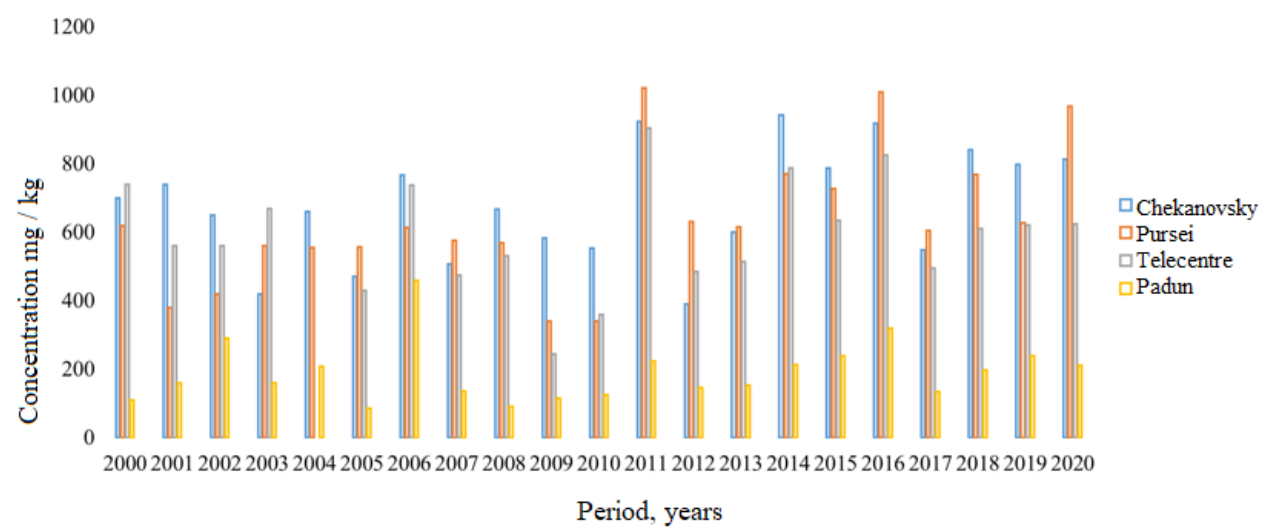

Fig. 2. The total content of fluoride compounds at the sampling points in Bratsk on the horizon of 5$10 \mathrm{~cm}$.

The content of more fluoride compounds at all points of sampling the soil of Bratsk on the horizon of $0-5 \mathrm{~cm}$ than on the horizon of $5-10 \mathrm{~cm}$ was found. The monitoring results indicate the maximum content of pollutants on the horizon of $0-5 \mathrm{~cm}$ in the village of Chekanovsky $-1,722 \mathrm{mg} / \mathrm{kg}$, in the Pursey greenhouse farm $-1,378 \mathrm{mg} / \mathrm{kg}$, in the area of the Telecentre $-1,314 \mathrm{mg} / \mathrm{kg}$ in 2011, in the village of Padun $-560 \mathrm{mg} / \mathrm{kg}$, which is 1.8 times more than the content on the horizon of $5-10 \mathrm{~cm}$ in the village of Chekanovsky ( $942 \mathrm{mg} / \mathrm{kg}$ ), 1.3 times more in the Pursey greenhouse farm $(1,022 \mathrm{mg} / \mathrm{kg})$, in the area of the Telecentre $(904 \mathrm{mg} / \mathrm{kg})$ more by 1.4 times, and in the village of Padun $(460 \mathrm{mg} / \mathrm{kg})$ more by 1.2 times. 
The assessment results of all monitoring sources of soil pollution in Bratsk, the Irkutsk Region, allowed identifying fluoride compounds as pollutants with the greatest negative impact on residential areas.

The analysis of the obtained data on the total fluoride content in the soil on the horizons of $0-5$ and $5-10 \mathrm{~cm}$ indicates that in Bratsk the area most polluted with these compounds is the village of Chekanovsky, and the least polluted are the soils of the village of Padun.

More reliable information about the peculiarities of the formation of the toxicological danger of soil pollution for the population is provided by the assessment of the intake of a chemical substance into the human body from the soil. The calculation of doses when assessing the risk of multi-mediated exposure to chemicals for the research period was carried out for oral, inhaled, cutaneous total exposure of the human body to soil chemicals.

The quantitative results of calculating the total intake of fluoride in the organisms of various population groups of Bratsk for 2007-2020 are presented in Table 1.

Table 1. Total intake of fluoride compounds into the human body from the soil, $\mathrm{mg} / \mathrm{kg}$ per day.

\begin{tabular}{|c|c|c|c|c|c|c|c|c|}
\hline \multirow{3}{*}{$\begin{array}{c}\begin{array}{c}\text { Date } \\
\text { of } \\
\text { samp }\end{array} \\
\text { ling, } \\
\text { year }\end{array}$} & \multicolumn{8}{|c|}{ Total intake of fluoride compounds, $\mathrm{mg} / \mathrm{kg}$ per day } \\
\hline & \multicolumn{2}{|c|}{$\begin{array}{c}\text { village of } \\
\text { Chekanovsky }\end{array}$} & \multicolumn{2}{|c|}{$\begin{array}{l}\text { Pursey greenhouse } \\
\text { farm }\end{array}$} & \multicolumn{2}{|c|}{ Telecentre area } & \multicolumn{2}{|c|}{ village of Padun } \\
\hline & Adults & Children & Adults & Children & Adults & $\begin{array}{l}\text { Childre } \\
\mathrm{n}\end{array}$ & Adults & $\begin{array}{l}\text { Childre } \\
\text { n }\end{array}$ \\
\hline 2007 & 0.583 & 1.361 & 0.535 & 1.250 & 0.411 & 0.959 & 0.106 & 0.248 \\
\hline 2008 & 0.708 & 1.652 & 0.616 & 1.438 & 0.512 & 1.195 & 0.096 & 0.223 \\
\hline 2009 & 0.647 & 1.511 & 0.286 & 0.667 & 0.255 & 0.596 & 0.064 & 0.150 \\
\hline 2010 & 0.731 & 1.706 & 0.323 & 0.755 & 0.407 & 0.950 & 0.072 & .168 \\
\hline 2011 & 1.036 & 2.417 & 0.807 & 1.884 & 0.868 & 2.026 & 0.183 & .427 \\
\hline 2012 & 0.343 & 0.800 & 0.590 & 1.377 & 0.400 & 0.934 & 0.076 & 0.177 \\
\hline 2013 & 0.570 & 1.330 & 0.509 & 1.187 & 0.486 & 1.135 & 0.128 & 0.298 \\
\hline 2014 & 1.039 & 2.424 & 0.770 & 1.798 & 0.576 & 1.345 & 0.151 & 0.353 \\
\hline 2015 & 0.741 & 1.728 & 0.683 & 1.595 & 0.607 & 1.418 & 0.228 & 0.532 \\
\hline 2016 & 0.916 & 2.137 & 0.935 & 2.181 & 0.719 & 1.677 & 0.233 & 0.544 \\
\hline 2017 & 0.569 & 1.322 & 0.506 & 1.186 & 0.489 & 1.134 & 0.127 & 0.299 \\
\hline 2018 & 1.038 & 2.421 & 0.773 & 1.797 & 0.574 & 1.346 & 0.152 & 0.352 \\
\hline 2019 & 0.743 & 1.727 & 0.681 & 1.594 & 0.601 & 1.417 & 0.229 & 0.533 \\
\hline 2020 & 0.912 & 2.136 & 0.936 & 2.180 & 0.718 & 1.679 & 0.235 & 0.543 \\
\hline $\begin{array}{l}\text { Aver } \\
\text { age }\end{array}$ & 0.7 & 1.7 & 0.6 & 1.4 & 0.5 & 1.2 & 0.1 & 0.3 \\
\hline
\end{tabular}

It is known that the human body's need for fluoride is about $0.03 \mathrm{mg} / \mathrm{kg}$ for adults and $0.15-0.1 \mathrm{mg} / \mathrm{kg}$ for children. Therefore, the body demand of the adult is $2.1 \mathrm{mg} / \mathrm{kg}$ per day, for children $-1.5 \mathrm{mg} / \mathrm{kg}$ per day.

The analysis of the total fluoride intake, $\mathrm{mg} / \mathrm{kg}$ per day for the adult, shows that the total average daily fluoride intake is not exceeded, but the maximum levels of the pollutant in the village of Chekanovsky are $1 \mathrm{mg} / \mathrm{kg}$ per day; in the Pursey greenhouse farm $-0.935 \mathrm{mg} / \mathrm{kg}$ per day; in the area of the Telecentre $-0.868 \mathrm{mg} / \mathrm{kg}$ per day.

The analysis of the total fluoride intake, $\mathrm{mg} / \mathrm{kg}$ per day for children shows that the total average daily fluoride intake is exceeded in the village of Chekanovsky (from 1.7 to 2.4 $\mathrm{mg} / \mathrm{kg}$ ); in the Pursey greenhouse farm (from 1.6 to $2.2 \mathrm{mg} / \mathrm{kg}$ per day); in the area of the Telecentre (from 1.68 to $2.03 \mathrm{mg} / \mathrm{kg}$ per day).

As a result of exposure to fluoride pollutants of the soil, on average for the adult, the total dose of fluoride compounds from the soil in the village of Chekanovsky is $0.7 \mathrm{mg} / \mathrm{kg}$ per day 
( $29 \%$ of the required average daily dose of fluoride for the adult); for children population $1.7 \mathrm{mg} / \mathrm{kg}$ per day (113\% of the required average daily dose for children).

The lowest total fluoride doses from the soil were detected in the village of Padun: for the adult, it was $0.1 \mathrm{mg} / \mathrm{kg}$ per day, which corresponds to $5 \%$ of the required average daily fluoride dose for the adult; for children $-0.3 \mathrm{mg} / \mathrm{kg}$ per day, which corresponds to $20 \%$ of the required average daily dose of fluoride for children.

The results of calculating the total fluoride intake in the organisms of various population groups in Bratsk for the period of 2007-2020 suggest that the village of Chekanovsky is a territory most polluted with fluoride compounds, it is followed by the territories of the Pursey greenhouse farm and the Telecentre area.

The findings of research to determine the fluoride content as a toxicant that has the ability to accumulate in the body and cause chronic intoxication showed that its concentration in the hair of people born and living in the Central District of the city is 2 times higher than that of residents of the Padun area, and the proportion of people with a high fluoride content in their hair is $12 \%$ of the number of the examined. At the same time, it is necessary to emphasize the increase in the fluoride content in the hair with age, which is probably due to its accumulation in the body.

Although fluoride is a vital trace element for a person, its increased content in the body is extremely dangerous and can lead to disruption of its work, up to a fatal outcome. The results obtained by us are in good agreement with the long-term research of T.I. Shalina [8] and other scientists [for example, 16, 18], confirming the dependence of the overall morbidity of children living in cities with man-caused air and soil pollution with fluoride compounds contained in the emissions of non-ferrous metallurgy plants on the example of cities of the Siberian Federal District. Significant differences in children and adolescents' morbidity were revealed, including an increase in the incidence of musculoskeletal diseases in children by 5.6 times, in adolescents - by 12 times [8].

Based on the aforesaid, it is important to identify all sources of fluoride compounds entering the natural environment at the regional level, to study the ways of their chemical transformations, to apply a system of measures to prevent environmental pollution with fluorine compounds. A quantitative assessment of the oral, inhaled, and cutaneous intake of this substance into the body from the soil will allow assessing reliably the impact of environmental and health factors caused by fluoride pollution on the formation of medical and biological indicators of public health.

\section{Conclusion}

1. Soil is the main component of land ecosystems that can accumulate fluoride compounds as pollutants. The predominant pollutant of the city's soils is fluoride compounds, the lack, and excess of which leads to quantitative and qualitative changes in the human body.

2. The high total fluoride content that has a toxic effect on the human body throughout the entire ontogenesis was revealed in the soils of the territory of the aluminium production plant.

3. Quantitative assessment of the intake of a chemical substance into the body from the soil allows calculating doses when assessing the risk of multi-mediated exposure to chemicals. The obtained results can be recommended for a comprehensive assessment of the environmental status of Bratsk, predictive assessments of the negative impact of man-caused environmental pollution on the health of various population groups, management of risk factors for the development of environmental-dependent pathology in the population in urbanized territories. 


\section{References}

1. Problems of protection and reproduction of natural resources. http://www.formergeographer.ru/forahs-762-2.html

2. R.F. Khasanova, Ya.T. Suyundukov, I.N. Semenova, Yu.S. Rafikova, Yu. Seregina, Hygiene and Sanitation 98(12), 1370 (2019)

3. N.V. Efimova, N.I. Matorova, N.N. Yushkov, V.A. Nikiforova, T.G. Pertseva, Medical and environmental risks of a modern city, 200 (Bratsk, 2008)

4. A.A. Petrova, E.V. Abakumov, Hygiene and Sanitation 98(5), 478 (2019)

5. L.A. Nikolaeva, D.A. Turchinova, Natural Science and Humanism 6(1), 58 (2010)

6. M.F. Savchenkov, L.A. Nikolaeva, Sibirskij medicinskij zurnal 100(1), 10 (2011)

7. G.A. Evdokimova, I.V. Zenkova, N.P. Mozgova, V.N. Pereverzev, Soil and soil biota under fluorine pollution, 155 (Publishing house of the Kola Scientific Center of the Russian Academy of Sciences, 2005)

8. T.I. Shalina, L.A. Nikolaeva, M.F. Savchenkov, Yu.N. Bykov, R.S. Manueva, Hygiene and Sanitation 95(12), 1133 (2016)

9. I.S. Antonov, N.A. Gradoboeva, Fluorine in soil and adjacent media in the zone of influence of the Sayan aluminum plant: observation results for 1989-1995. In tables and explanations, 67 (GSAS "Khakasskaya", 1996)

10. G.A. Evdokimova, I.V. Zenkova, Soil Science 8, 973 (2003)

11. A.A. Kozlova, O. G. Lopatovskaya, N.I. Granina, E.V. Chipanina, E.V. Kuchmenko, A.N. Bobrov, Izv. Irk. state University, series "Biology. Ecology "4(1), 87 (2011)

12. A. Bobrov, Mater. All-Russian. scientific. conf. "Soils under natural and anthropogenic stress", 112 (2011)

13. Problems of protection and reproduction of natural resources. http://www.formergeographer.ru/forahs-762-2.html.

14. E.P. Yanin, Environmental Expertise 4, 98 (2007)

15. I.V. Donskikh, Bulletin of the All-Russian Scientific Center of the Siberian Branch of the Russian Academy of Medical Sciences 3(91), Part 2, 179 (2013)

16. V.N. Kuvina Ecologically caused pathology of the musculoskeletal system of children in Eastern Siberia, 235 (Irkutsk, 1991)

17. A.Yu. Gaskov, M.F. Savchenkov, N.N. Yushkov, Hygiene and Sanitation 6, 53 (2005)

18. M.V. Mintel, M.A. Zemlyanova, I.G. Zhdanova-Zaplesvichko, Human Ecology 9, 12 (2018)

19. T. Damstra, S.Barlow, A. Bergman, R. Kavlock, G. Kraak, Global Assessment on the State of the Science of Endocrine Disruptors (Geneva, 2002)

20. T. Kjellstrom, S. Friel, J. Dixon, C. Corvalan, E., J Urban Health. 84(1), 86 (2007)

21. X. Bai, I. Nath, A. Capon, D. Hasan, D. Jaron, Current Opinion in Environmental Sustainability 4(4), 465 (2012)

22. K.J. Maji, A.K. Dikshit, A. Deshpande, P.C. Speldewinde, Cogent Environmental Science 2(1), (2016)

23. A. Schecter, N. Malik-Bass, A.M. Calafat, K. Kato, J.A. Colacino, T.L. Gent, L.S. Hunan, T.R. Harris, S. Malla, L. Birnbaum, Health Perspect 120(4), 590 (2012)

24. M. Pereira, P.A. Dombrowski, E.M. Losso, L.R. Chioca, C. Da Cunha, R. Andreatini, Neirotox Res 19(1), 55 (2011)

25. B. Ravichandran, S. Chattopadhyay, P.K. Gangopadhyay, H.N. Saiyed, Toxicol and Environ Chemical 94(10), 2052 (2012)

26. C. Palmer, S.H. Wolfe, J. Am. Diet. Assoc. 105(10), 1620 (2005)

27. Maximum permissible concentration (MPC) of chemicals in the soil: GN 2.1.7.2040-06, 172 (M., 2006)

28. Determination of fluorine in soil, vegetation, fallout, in the air and natural waters by the 
method of ion-selective electrode: temporary MU (M., 1980)

29. Calculation of doses in assessing the risk of multi-media exposure to chemicals: MosMR 2.1.9.003-03, 28 (M., 2003) 